\title{
SYNJ1 Gene
}

National Cancer Institute

\section{Source}

National Cancer Institute. SYN/1 Gene. NCI Thesaurus. Code C114737.

This gene plays a role in clathrin-mediated endocytosis. 